\title{
Why Regionalism May Increase the Demand for Trade Protection
}

\author{
Sanoussi Bilal \\ European Institute of Public Administration
}

\begin{abstract}
This paper examines the influence of regional integration on the demand for trade protection. Previ ous studies have suggested the a customs union reduces the pressures for trade restrictions, as national interest groups have less weight to influence a central trade authority than their own government. On the con trary, this paper argues that protectionist preferences may not be di luted at the regional level. The reasons for this lie in the ability of protection interests to organize themselves at the regional level and the advantage they have over anti-protectionist forces in doing so ( principally due to their superi ority in con trolling the potential free rider problem). In consequence, specific groups seek ing external protection are likely to experience a relative (if not absolute) rein forcement of their preferences in a trade bloc. (JEL Classification: D72, F 13)
\end{abstract}

\section{Introduction}

During recent years, regional trading agreements (RTAs) have blos- 
GATT, which represents 30 percent of the total number reported since 1947 〈WTO [1995]〉. This surge in regionalism interest has been accompanied by a deepening and widening of existing agreements, in particular the European Union (EU).

The resurgence of regionalism has attracted much attention from the economics profession. Most studies concentrate on the formation and expansion of trade blocs, and their impact on protection levels and on liberalization, highlighting the potentially conflicting objectives and influences of regionalism versus multilateralism 〈for a recent survey, see B hagwati and Panagariya [1996]; Sager [1997]; and Winters [1996].$^{1}$

The political economy aspects of regional integration are crucial to understand trade stances adopted by trade blocs and their influence on the multilateral system. In particular, the analysis of the demand for and the supply of protection in an RTA, neglected in most studies, deserves attention: Do RTAs increase or decrease protection-seeking activities? Note that this issue is different, although related, to the standard question on trade blocs: Do RTAs increase or decrease the level of trade protection? /see for instance Frankel, Stein and Wei [1996]; Hallett and Braga [1994]; and Krugman [1993]).

The political economy approach focuses on the pressures for trade protection (at the domestic and regional level) and the responsiveness of the relevant trade authorities to these specific demands. Three principal factors can be identified: the free riding problem, anti-protectionist forces, and insti tutions. First, since the size of interest groups increased (as they can get organized at the regional, and not only national, level), free riding may affect their behaviour. Hence: Can interest groups become politically more efficient in an RTA? Second, anti-protectionist forces are affected by regional integration. Then: Are protection-seeking groups more likely to overcome 
answer to these three questions. The purpose of this paper is to address the first two questions, related to the demand for trade intervention, leaving the institutional aspects of RTAs and their influence on the supply side of protection for another study 〈see Bilal [1998]〉.

The discussion is organized as follows. Section II introduces the concept of the preference-dilution effect commonly assumed in studies on the political economy of trade in the context of regional integration. The free riding issue is addressed in Section III, while Section IV discusses lobbying efficiency at the regional level. These sections show that in many circumstances the absolute political influence of protection-seeking groups may increase as a result of a trade bloc formation. Section $V$, focusing on anti-protection forces, argues that relative political influence is what matters. Regional integration is likely to strengthen the position of protection seekers vis-à-vis their opponents. The main arguments are summarized in Section VI.

\section{The Preference-Dilution Effect}

A common answer to the question of how RTAs affect protection-seeking behaviours is that protectionist pressures decrease as a result of a regional integration. The contention is that interest groups being organized at the national level, the formation of a trade bloc reduces their relative size and therefore their influence at the regional level. De M elo, Panagariya and Rodrik [1993] refer to this phenomenon as the "preference-dilution effect". In their words:

"Irrespective of the institutional setup, a regional arrangement implies a larger political community and hence a smaller role in determining policy for politically important groups in each of the 
down, the groups rationally choose to do less of it." (p.180). ${ }^{2}$

$\mathrm{N}$ ational preferences may also be diluted for another reason. As the trading bloc becomes larger, interest groups can experience difficulties to organize themselves at the regional level. To seek external trade protection, national pressure groups may therefore choose to coordinate (or combine) their effort with their counterparts (who share similar interests) in partner countries. The free riding problem associated with the larger number of groups with similar interests at the regional level may participate to the preference-dilution effect experienced by national lobbies in trade blocs. Panagariya and Findlay [1996] of fer a formal analysis of the free-riding problem in lobbying associated with an RTA, and in particular a customs union, developing a $M$ eade model which allows for trade policy to be determined endogenously. The free-riding component of the preference-dilution effect is perfectly consistent with the logic of collective action, as described by Olson [1965].

This type of consideration based on the preference-dilution effect (although generally only implicitly) have led economists like Panagariya and Findlay [1996], Richardson [1994], and Sinclair and Vines [1994] to conclude that a customs union (CU) will tend to be less protectionist than a free trade area (FTA). ${ }^{3}$ The argument proceeds as follows.

Assuming that trade policy is fully endogenous, the level of protection will depend on the lobbying activities of pressure groups. In an FTA, wherein each member country can set individually its own trade policy with non-

2. Although the formal model developed by de Melo et al. [1993] is inspired by the credibility analysis in macroeconomics, their conclusion is consistent with some of the standard models of the political economy of trade literature 〈see M agee, Brock and Young [1989] $\rangle$.

3. An alternative line of argument is provided by Krueger [1995] who pursues a different approach ( to reach similar conclusions). In short, she most convincinqlv arques 
member countries, domestic interest groups need only to lobby their own government to influence the non-FTA level of protection. Therefore, in an FTA protection has the characteristics of a private good. In a CU, however, the external trade policy being common to all member countries, domestic pressure groups have to exercise their influence at the union level as well. Thus, at the union level protection becomes a public good subject to the free-riding problem. M oreover, the regional decision-making body is likely to be less favorable to country-specific lobbying than national authorities, since it has to balance (potentially conflicting) specific interest demands from CU members. In consequence, some degree of coordination among national interest groups may be required in order for lobbying activities to affect external trade policies. The reduction in national lobbying influence at the union level and the increased free riding problem resulting from common lobbying activities represent two aspects of the preference-dilution effect associated with a CU but not present in an FTA.

At first, this explanation seems convincing. Actually, it may accurately describe the regional integration outcome, at least in some cases. However, this argument relies on four crucial assumptions. First, the free riding problem cannot be efficiently overcome by protection-seekers. In fact, de M elo et al. [1993] justify their setting by making the assumption of non-cooperation by lobbies across countries. That is, interest groups are unable to organize themselves at the regional level (as in the analyses by Richardson [1994]; and Sinclair and Vines [1994]>. Second, there is no effective counter lobbying at the regional level (i.e., lobbying against protection, for instance from the part of consumers). Third, the fact that trade restrictions adopted by a $\mathrm{CU}$ affect a larger number of people than national protection (phenomenon sometimes refer red to as the "contagion" effect) is disregarded. Finally, the "institutional setup" does not matter. The first three assumptions are exam- 
ing from trade policy. ${ }^{4}$ However, the larger the potential size of the interest group, the larger is the incentive, by each member of the group, to free ride. Hence, the lower is the chance of success by the pressure group. In sum, for lobbying, small is better than large. ${ }^{5}$

\section{A. Olson's Logic of Collective Action}

This argument corresponds to a mechanical application of The Logic of Collective Action as described by Mancur Olson [1965]. Focusing on the effect of group size on the provision of public goods by private groups, this theory suggests that the larger the group size, the larger the level of free riding, and thus the lower the amount of public good provided. ${ }^{6}$ The rationale can be summarized as follows. An individual will contribute to the provision of a public good only if the (expected) benefits exceed the costs of doing so. As the size of the group increases, the cost of collective action (in the sense of adopting efficient organization structures with appropriate incentives and control mechanisms insuring the participation of group members) rises. Simultaneously, the relative importance of each member contribution for the viability of the collective action falls. That is, the free riding problem increases with the size of the group, as the probability that the public good will be voluntarily provided depends less strongly on each individual contribution. However, as the number of free riders rises, (1) the risk that the public good will not be provided at all increases, and (2) the burden on the active members of the group increases.

4. The discussion focuses on trade policies but can easily be generalized to any redistributive policy common to the whole region.

5. Pushed to the limit, however, this argument would tend to suggest that pressure arouns are more active in small countries than in larae ones. Hence. ceteris baribus. 
Besides, when the benefits from collective action differ among members of the group, "there is a systematic tendency for the "exploitation" of the great by the small" $\langle$ OIson [1965], p. 29〉. Hence, a high variance in the distribution of interest among group members increases the probability that the collective good will be provided, as it is then more likely that at least one member of the group will find in his interest to provide some of the public good 〈see also Stigler [1974]; M arwell and Ames [1979]; and M agee et al. [1989]). This seems especially pertinent in small groups.

The argument based on the variance of preferences in the group is formally different from the one based on the size of the group. However, the two concepts are linked to the extent that not only large groups are more subject to the free rider problem (the size argument), but they may also be exposed to a greater diversity of interests among members than small groups (the variance argument). The following discussion will show, however, that the logic of collective action can be challenged at both the theoretical and empirical level (in sections III. B and III. C, respectively).

\section{B. The Influence of Size Group Reconsidered}

Contrary to Olson theory, several studies have shown that the provision of collective goods could as well increase with group size.

For instance, Chamberlin [1974] and M cGuire [1974] argue that, for normal (public and private) goods, the non-rivalness property of the public good implies that the decrease in the individual contribution to the provision of collective goods is countered by the increase in group size. The positive income elasticities of the public and private good insure this result, as the spillover of collective benefits from other contributions generates positive income effects; additional members do not reduce the benefits of collec- 
Generalizing these results, Austen-Smith [1981] introduces uncertainty as a factor influencing the individual level of contribution to the provision of collective good. In particular, he shows that, for risk-averse individuals, (1) under specific conditions, ${ }^{8}$ uncertainty concerning the level of other group members' contributions increases the individual own's contribution to collective action; and (2) uncertainty concerning the rate of returns of productive activities increases the level of individual contributions to collective action, while the impact is ambiguous at the group level 〈on this issue, see also M urphy, Schleifer and Vishny [1991]).

Fon [1988] finds similar results. Besides, Eichberger and Kelsey [1996] show that (Knightian) uncertainty can reduce free-riding in a large society, the sufficient condition being the concavity of either the utility function or the production function of the public good (rather than risk-aversion). To the extent that lobbyists tend to seek protection to reduce the uncertainty surrounding a regional integration process or that lobbying activities exhibit decreasing returns to scale (at least over a certain range), their analysis would suggest that RTAs may contribute to reduce the free-rider problem of protection-seekers.

Recent contributions in the rent-seeking literature also suggest that participants in rent-seeking contests have incentives to voluntarily form a competitive-share group 〈Baik and Shogren [1995]〉. Moreover, collective rentseeking increases with group size, despite the existence of free riding $\langle$ Riaz, Shogren, and J ohnson [1995]).

$M$ ore generally, the conventional prediction that collective goods are not likely to be voluntarily provided because of the free rider problem (particularly important in large groups) has been challenged by many authors. For instance, B rubaker [1975] suggests that the free riding hypothesis may be weakened, even in large groups. He presents this weak version of free rid- 
ture. The strong version states that no public good will be provided, while the weak version asserts that free riding problems will lead to an under-provision (i.e., below the Pareto-optimal level) of the public good (see also Fon [1988]>. A survey on the theory of voluntary collective action is beyond the scope of this study. It is sufficient to note that the (strong) free riding hypothesis has been questioned on theoretical grounds. The general conclusion emerging from these various approaches is that a collective good may be voluntarily provided 〈for instance, see Bergstrom, Blume, and Varian [1986]; Guttman [1991]; and Hirshleifer [1983]).

\section{Empirical Evidence on Free Riding}

Numerous empirical studies aiming at testing the existence of free riding have been conducted. The most common approach consists in undertaking laboratory experiments. However, the results remain inconclusive. Several papers find weak or no support for the free riding hypothesis (see $\mathrm{M}$ arwell and Ames [1979]; I saac, Walker and Thomas [1984]; and Isaac, Walker and Williams [1994]), whereas others, like Kim and Walker [1984], suggest opposite results, supporting the strong version of free riding.

The few tentative analyses in non-laboratory settings do not seem much more conclusive. Hansen, Palfrey and Rosenthal [1987] for instance, analyzing the constituency size effect in voter turnout rates, found support for the free rider problem in large groups. But Coates and M unger's [1995] analysis on strategic behaviour suggests that while some degree of non-cooperative behaviour is common, cooperative behaviour is also frequent. Hence, the strong free riding hypothesis seems to be rejected. Similarly, in his empirical analysis on per church member contributions, Lipford [1995] rejects the hypothesis that the free-rider problem increases with larger 


\section{Lobbying Efficiency}

\section{A. Free Riding or Cooperation?}

With regard to RTAs, free riding may appear as a likely outcome. However, there are many instances where free riding problems may be overcome. As the regional entity widens, the various interest groups may find it desirable to organize themselves. Regional integration tends to increase the potential size of pressure groups. Consequently, as argued in the theory of free riding, the relative stake of each individual member in the interest group falls as the region expands. Hence, with the lobbying power of each individual firm decreasing, a more formal organization as well as the development of new structures of the interest group may become necessary. ${ }^{9}$

For the sake of illustration, consider the simple case where previous to regional integration a large firm, or a set of firms concentrated in one area, represents the principal protection-seeking group for that industry at the national level, allowing for other (small) domestic firms to free ride. According to the preference-dilution argument, once regional integration takes place the large (set of) firm(s) sees its influence diminish. However, if the industry as a whole wants to obtain (or maintain) some kind of protection at the regional level, the development of (transnational) organization or association may constitute the only effective way of influencing regional trade policies. F or small firms the incentive to free ride may in fact decrease, contrary to the prediction from the preference-dilution effect, as they can no longer rely on the lobbying efforts of the few large firms to obtain protection for the industry. Once in place, these transnational pressure groups may become more effective in shaping trade policies at the regional level than their (less organized) counterpar ts were at the national level. 
interest group model (in the OIson tradition) which assumes that only small concentrated groups will be able to lobby efficiently (as they can control the free riding problem), the adding-machine model predicts that an industry composed of many geographically unconcentrated firms may have an advantage in lobbying as they naturally appeal to more districts' interests.

$B$ ased on the assumption that the objective of the government is to maximize its chances of being re-elected 〈see D owns [1957]), this model explicitly recognizes the importance of logrolling (i.e., vote trading). As many issues cannot be disentangled, the formation of majority coalition resulting from trade-off and exchanges of support ("favors") among coalition members becomes a central feature of legislative activities, necessary to ensure the passage of package measures.

Hence, a protection-seeking industry concentrated in one district may not be able to gather sufficient political support in other districts to insure a majority coalition in favor of its request. A vote-maximizing government will not respond favorably to this protectionist demand, as it would alienate more districts, and therefore more voters, than it would attract electoral support from the area where the industry is concentrated. Conversely, a geographically widespread industry can generate greater political support as (at least some) voters in a larger number of districts will have an interest in protecting that industry.

The adding-machine model suggests that the likely impact of RTAs will be to increase the demand for protection at the regional level, subject to the condition that an industry is not concentrated in one country only, but dispersed throughout the region. ${ }^{10} \mathrm{M}$ oreover, an industry too weak to obtain political support in each country member may choose to coordinate its efforts at the regional level in order to influence the centralized common authority. 
gration may provide the momentum necessary for the development of organized lobbying from that industry within, and across, the different member countries. This could be called a "preference-diffusion" effect, or "demonstration" effect (running contrary to the preference-dilution effect).

Various factors can explain such an occurrence. The concerned industry at the regional level may benefit, in its lobbying activities, from the experience, the structure, the know how ("savoir faire") of its successful "branch(es)" in one area. Such successful national branches of the industry may act as leader in the pressure group at the regional level. They may also help in arousing attention and awareness of less (politically) active parts of the industry to lobbying opportunities. Although some of these elements may not depend on the existence of regional integration, the need for cooperation among national interest groups in a trade bloc clearly stimulates the process by which preferences are diffused across the region. Typical examples seem to include the agriculture lobbying in the EU (extremely well organized in some large countries - like France - whose influence appears to have spread over the EU) as well as the European steel industry with Eurofer.

\section{Economies of Scale in Lobbying}

Consistent with the demonstration effect co-exists another type of argument based on economies of scale in lobbying. As suggested by Findlay [1993, p.197]:

"An obvious and realistic example of greater potential mischief the wider is the policy making entity is provided by the familiar "economies of scale" argument for protecting industry in developing countries. The limited size of the individual national market

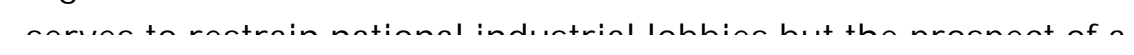


First, the structure of rent-seeking technology exhibits increasing returns when there is a fixed cost associated with the setting up of a rent-seeking system. The development of a legal code and the organization of pressure groups are costly processes; but once in place, they can be "used" at a decreasing marginal cost. To a large extent, the EU experience provides a good illustration of this phenomenon. The development of EU institutions, the shaping and the implementation of external trade rules and policies, as well as the setting up of pressure groups and industrial associations at the Union level have induced large fixed costs in rent-seeking. However, once the system is in place, lobbying at the European level seems to have become a common practice. The flourishing of professional lobbyists, legal consultants and $\mathrm{EU}$-wide industrial associations suggest increasing returns to scale in lobbying, to a certain degree at least.

The second form of increasing returns to rent-seeking follows from the interaction between rent-seeking and productive activities. The interesting feature of Murphy et al.'s [1993] framework is that the "generic" form of increasing returns in lobbying does not depend on the assumption of increasing returns in rent-seeking technology. On the contrary, assuming that rent-seeking technology exhibits decreasing returns, as do productive activities, they show that, at least over some range, rent-seeking exhibits general equilibrium increasing returns. Indeed, as resources are diverted from the productive sector to the benefit of directly unproductive profitseeking (i.e., lobbying) activities, returns to production may fall faster than returns to rent-seeking over a certain range, hence reducing the relative attractiveness of productive (vis-à-vis lobbying) activities. ${ }^{11}$ This might be the case for some domestic industries adversely affected by an RTA, as discussed in the next section. 
others. The "losers" from free trade inside the region may seek protection against the rest of the world as a compensation. Adverse economic conditions and loss of competitiveness for these industries "injured" by regional integration may lead trade authorities to respond more favorably to demands for external protection.

Actually, in a period of adversity and economic distress, injured industries tend to seek protection (and more generally government support) more forcefully than otherwise. Indeed, economic rents can be obtained from either productive or lobbying activities. A rational private agent will engage in the activity which yields the highest net return 〈e.g., see M urphy et al. [1991]). In a period of economic decline, an industry may find relatively more profitable to pursue regulation (such as protection) through lobbying activities (whose opportunity cost falls in depression) than to engage in costly restructuring reforms. Hence, the incentive to free ride by potential members of a pressure group declines, as their individually perceived benefits from active trade policy (and more generally government intervention) increase. This is often refer red to as the "compensation effect" $\langle M$ agee et al. [1989], ch.11; see also Baldwin [1993], for a discussion). ${ }^{12}$

\section{F. Influence of Group Size and Concentration on Lobbying: Empirical Evidence}

It appears the impact of group size and concentration on the contribution to and success from collective action cannot be determined at the theoretical level as conflicting factors come into play. Consequently, confirmation of the logic of collective action must rely on empirical findings. In this respect, two categories of empirical studies can be identified. The first one relates to the relationship between concentration and the level of political influence 
early survey, see E pstein [1980]〉.

\section{1) Concentration and Political Influence}

The main empirical support in favor of a positive correlation between the level of political influence and industrial concentration is provided by Pittman [1976, 1977, 1988]. Looking at the influence of political contribution by American industries on government policies, he concludes that lobbying activities is only undertaken by firms in highly concentrated industries. Several independent studies seem to partially confirm his findings. In particular, Grier, M unger and Roberts' [1994] results indicate that industrial concentration is positively related to both the decision to lobby and the amount of contribution dedicated to influence politicians. But this positive relation holds only over a certain range (see discussion below). Esty and Caves [1983] show that seller concentration positively affects the level of political activity and success.

On the contrary, many studies have failed to find a positive link between concentration and political influence. Indeed, Posner [1974] and Salamon and Siegfried [1977] suggest that industry concentration may negatively affect the chance of the industry in obtaining favorable regulation.

While making the important distinction between the level of political activity and political success by a lobbying industry, Esty and Caves [1983] indicate that neither firm size nor industry size have a robust influence on political activity or success. Moreover, geographical dispersion increases both political activity and success, the latter to an even greater extent than the former. This result is partly supported by Grier et al. [1994].

One of the strongest rejections of Pittman's results has been provided by the work of Zardkoohi [1985, 1988] who argues, both at the theoretical and empirical level, that industry concentration does not significantly affect the 
cal activity can in fact be represented by a concave quadratic function. Hence, a regression between these two variables could show a positive or a negative relationship, depending on the range of concentration ratio (i.e., on the section of the concave curve). In a different context, M esserlin [1989] suggests a similar relationship. M easuring the lobbying power of industries protected by antidumping duties in the $E U$, he noted that coalitions of few firms were the most "efficient" in obtaining protection.

\section{2) Size, Concentration, and Trade Restrictions}

Turning to the empirical literature on trade, it is not possible either to find unambiguous support for Olson's theory. According to the interest group model, whose foundations rest on Olson's logic of collective action, the level of protection should be related, among other things: (1) negatively to the number of firms in the industry; (2) positively to the industry concentration ratio; and (3) positively to the geographical concentration.

Some of the main empirical analyses on the determinants of protection are summarized in Table 1. Very few studies seem to provide overall support for the pressure group model. A notable exception is the analysis by Pincus [1975] on antebellum tariffs in the United States. He finds a positive correlation between U.S. nominal duties in 1824 and both industry and geographic concentration. Several empirical findings offer only partial support for some of the pressure group model's hypotheses. However, numerous studies fail to find any support for these three hypotheses at the core of the pressure group model.

Besides, a specific result may be worth mentioning. In his empirical analysis, Lavergne [1983] identifies a positive link between the level of protection (in particular nominal tariffs and non-tariff barriers) and the population size of the state where an industry is located. This result suggests that 
Table 1

Determinants of Levels of Manufacturing Industry Protection

\begin{tabular}{|c|c|c|c|c|c|c|c|c|c|c|c|c|}
\hline \multirow{2}{*}{\multicolumn{2}{|c|}{$\begin{array}{l}\text { Endogenous variables } \\
\text { Exogenous variables }\end{array}$}} & \multicolumn{3}{|c|}{$\begin{array}{c}\text { Nominal } \\
\text { Tariffs }\end{array}$} & \multicolumn{3}{|c|}{$\begin{array}{c}\text { Effective } \\
\text { Tariffs }\end{array}$} & \multicolumn{3}{|c|}{$\begin{array}{c}\text { Non-Tariff } \\
\text { Barriers }\end{array}$} & \multirow{2}{*}{ Notes: } & \multirow{2}{*}{$\begin{array}{l}\text { The }+ \text { and }- \\
\text { signs indicate } \\
\text { the sign of the } \\
\text { estim ated }\end{array}$} \\
\hline & & $\mathrm{nf}$ & ic & gc & $\mathrm{nf}$ & ic & gc & nf & ic & gc & & \\
\hline \multicolumn{2}{|l|}{ B elgium } & & & & & & & & & & & regression \\
\hline \multicolumn{2}{|l|}{ Tharakan [1980] } & & + & $--^{b}$ & & $+1-$ & $--^{\mathrm{b}}$ & & $-{ }^{c}$ & $+^{c / d}$ & & $\begin{array}{l}\text { coefficients; } \\
\text { a. } 1 \% \text { level }\end{array}$ \\
\hline \multicolumn{2}{|l|}{ B razil } & & & & & & & & & & & significance; \\
\hline \multicolumn{2}{|l|}{ Amelung [1989] } & & & & & $t^{a}$ & $+^{a / b}$ & & & & & b: $5 \%$ level; \\
\hline \multicolumn{2}{|l|}{ Canada } & & & & & & & & & & & c: $10 \%$ level; \\
\hline \multicolumn{2}{|l|}{ Caves [ 1976] } & & $-{ }^{b}$ & $+^{\mathrm{b}}$ & & $-{ }^{b}$ & $-?$ & & & & & $\begin{array}{l}\text { d: } 15 \% \text { level; } \\
\text { ?. significant }\end{array}$ \\
\hline \multirow{2}{*}{ Helleiner [ 1977] } & 1961 & & + & & & $+^{\mathrm{b}}$ & & & & & & (at an unspeci- \\
\hline & 1970 & & + & & & - & & & & & & fied level) \\
\hline \multicolumn{2}{|c|}{ Saunders [1980] } & & & & & + & & & & & & $\mathrm{nf}=$ number of \\
\hline \multicolumn{2}{|l|}{ France } & & & & & & & & & & & firms in the \\
\hline & & & & - & $-b$ & & $t^{\mathrm{b}}$ & + & & & $\begin{array}{l}\text { Industry } \\
\text { ic = industrial }\end{array}$ \\
\hline \multirow{2}{*}{\multicolumn{2}{|c|}{$\begin{array}{l}\text { Israel } \\
\text { Kahane [1992] }\end{array}$}} & & & & & & & & & & & concentration \\
\hline & & & & & $-^{b}$ & & & - & $+^{\mathrm{b}}$ & $+^{\mathrm{b}}$ & & $\mathrm{gc}=$ geo- \\
\hline \multicolumn{2}{|l|}{ Sweden } & & & & & & & & & & & graphical con- \\
\hline & & $+^{\mathrm{b}}$ & & & $+^{\mathrm{b}}$ & & & & & & \\
\hline \multicolumn{2}{|l|}{ United States } & & & & & & & & & & & \\
\hline \multicolumn{2}{|l|}{ Baldwin [1985] } & $--^{b}$ & + & & & & & - & - & & & \\
\hline \multicolumn{2}{|l|}{ Godek [1985] } & $--^{b}$ & & + & & & & - & & $t^{\mathrm{b}}$ & & \\
\hline \multirow[t]{3}{*}{ Lavergne [1983] } & $1964-65$ & & $+^{c}$ & - & & + & + & & + & + & & \\
\hline & 1972 & & $+^{\mathrm{c}}$ & - & & + & $+^{\mathrm{b}}$ & & & & & \\
\hline & $1970-80$ & & - & + & & & & & - & - & & \\
\hline \multicolumn{2}{|c|}{ M arvel and Ray [1983] } & & + & & & & & & $-{ }^{b}$ & & & \\
\hline \multicolumn{2}{|c|}{ Pincus [1975] } & & $+?$ & $+?$ & & & & & & & & \\
\hline
\end{tabular}


from regional and sectoral pressure in a democracy [...] is most easily achieved with large electoral districts" 〈see also Atlas et al. [1997]〉.

To summarize, if the discrepancy in findings does not allow a rejection of the preference-dilution hypothesis, it suggests at least that this argument should not be applied in a "mechanical way" to the analysis of RTAs. There exist not only theoretical but also empirical reasons to be cautious (if not suspicious) about the relevance of the preference-dilution argument.

\section{G. Further Considerations on Market Structure and \\ Political Influence}

The theory of regulation, as developed by the Chicago school 〈see Stigler [1971]; and Peltzman [1976]), suggests that market structure also plays an important role in lobbying activity in order to influence regulatory outcomes. According to this literature, industries facing fierce competition may try harder to shelter behind protective regulation (as a substitute to oligopolistic rents) than monopolistic industries. The latter may benefit from barriers to entry restricting both domestic and foreign (potential) competitors, consequently reducing their need for protection. Besides, although the costs of collective lobbying may be lower in oligopolistic industries, it may be politically more difficult to overtly grant trade protection to such industries which already enjoy favorable market positions.

The theoretical presumption that oligopolistic industries are less involved in lobbying activities and have less political influence than competitive industries is confirmed by many empirical studies 〈see Anderson and Baldwin [1981]; Esty and Caves [1983]; Glazer, M CM illan and Robbins [1985]; M agee et al. [1989]; M ann and M cCormick [1980]; and Pugel and Walter [1985]). To the extent that RTAs, by abolishing internal barriers to trade, 
administered path to protection (which includes antidumping, anti-subsidy and safeguard measures) plays a major role in present trade policy mechanism. The specificity of the regulation on administered protection offers opportunities to avoid the free riding problem which may be associated with collective action directed at influencing political trade decisions.

Regional integration does not dilute preference for protection when the petitioner seeking administered protection does not have to be representative of the whole union industry, but only of his own country industry. In fact, external trade protection in a CU may become more accessible at the administered than political level, in which case the demand for protection might shift away from political protection to administered trade remedy procedures 〈see for instance Bilal [1997]; and M oore and Suranovic [1992]〉. If the regulation on administered trade rules does not require the petitioner to be representative of the industry at all, then individual firms may seek protection on their own. In this case, there is no dilution of preference at all, in the sense that it is not more costly or difficult for an individual protectionseeker to pursue administered protection at the union than national level.

Actually, administered protection procedures may be designed to facilitate the filing of petitions by small firms or industries, as it is the case in the U.S. 〈see Horlick [1990]〉 and recently in the EU. Hence, even though free riding may exist, regulations may guarantee the access of administered trade remedy procedures to single firms (by keeping the cost of filing a petition at a low level or supporting small petitioners in the complaint procedure), reducing the need for collective action.

The incentive to pursue the administrative path to protection would be further enhanced if, as suggested by the preference-dilution argument and the Olson's logic of collective action, the political path to protection became less accessible to national protection-seekers 〈see Bilal [1998]〉. 
activities) and that, following an RTA, protection-seeking groups experience a "dilution" of their preference. Then, what matters is the relative, not absolute, efficiency in lobbying (as emphasized by Becker [1983]). Consequently, in order to assess the relative political influence of protectionist interests, it is also necessary to consider the influence of regional integration on anti-protectionist groups.

Indeed, RTAs result from a compromise between protectionist and antiprotectionist forces. F ree trade support originates mainly from consumers, industries relying on imported inputs, and the export sector, whereas import-competing industries tend to actively support restrictive trade practices. These antagonistic interests influence both the process of regional integration and the external regional trade policy.

The politics of FTAs has been formally discussed by Grossman and Helpman [ 1995]. They conclude that support for an FTA is more likely when (i) trade diversion is high and there is no (or a low level of) trade creation (see also Krueger [1993, 1995]) and (ii) when the industries most opposed to the regional integration can be excluded from the agreement, or at least be granted long periods of adjustment. That is, as seen in the previous section, the support of opposing interests can be "bought off" (i.e., the opposition can be diffused) in three different ways: (1) by protecting import-competing industries against extra-regional imports, (2) by providing a long period of adjustment, and (3) by excluding some sectors from the agreement. ${ }^{13}$ Consequently, RTAs can generate a widespread consensus. As stated twenty years ago by Fritz M achlup [1977, p. 102]:

"A custom union or any regional trade bloc may be seen as a compromise between two groups of antagonists promoting seemingly irreconcilable principles of policy: free-traders and protectionists. 
not only on the demand for "compensation"14 from protectionist interests, but also on the pressure against trade restrictions from anti-protectionists.

It is likely that the gainers from free trade will be more numerous than the losers. Typically, trade protection greatly benefits a small proportion of economic agents (mainly, some import-competing sectors) while hurting the majority (mainly consumers). However, as the costs of protection, although potentially significant, affect a large proportion of the population, they are diffuse. Hence, the incentive for anti-protectionist forces to get organized tends to be weak, since (1) the share of the burden from protection per individual is small, implying that the individual benefits from collective action are small too, and (2) the relatively large number of individuals negatively affected by protection implies high costs of collective action due to coordination and free riding problems.

While these factors explain the predominance of protectionist interests in the determination of trade policy at the national level (at least to a certain extent), their significance may be magnified by a regional integration which, by definition, increases the number of individuals affected by protection. Therefore, in absolute terms, the preference-dilution effect could well be larger among anti-protectionist forces than among protection-seeking interests.

In other words, by incorporating anti-protectionist lobbying into the analysis, it is possible to explain why protection could increase as the result of regional integration, in spite of the potential growing free rider problem associated with trade bloc formation. Protection generates a few, generally large, "gainers" at the expense of a great number of usually small "losers". As the region expands, the former tend to experience relatively less free riding problems and lower organizational difficulties than the latter. Hence, regional integration may lead to a relative increase in the influence of protectionist groups. M oreover, to the extent that groups seeking specific protection are 
obtained is sufficiently large to attract general public attention and/ or raise sufficient concern among anti-protection forces. Actually, if regional integration intensifies the visibility of (and the sensitivity to) trade policy issues, and significantly damages the interests of large groups (such as consumers) or dominant sectors of the economy, the benefits from anti-protectionist activities may become significant enough to overcome the large (mainly fixed) organizational costs due to free riding. In such a case, the free trader lobby may become relatively more active and successful than the protectionist lobby in shaping trade policies..$^{15}$

In conclusion, although protection-seekers may see their absolute political influence reduced following a regional trading agreement, there is no reason to expect a relative dilution of their protectionist preferences a priori.

\section{Conclusion}

Over the last few years, RTAs have flourished. This renewed interest for regionalism has attracted tremendous attention from the economics profession. The main issues have been the impact of trade blocs on protection levels and on the trade liberalization process, as well as the potential conflicting objectives and impacts of regionalism versus multilateralism. This paper analyzes the political economy of regional integration, focusing on the demand for protection, an issue often neglected in the current literature. The few studies concerned with this problem tend to apply, in a rather mechanical way, the concept of free riding or simply ignore the possibility of cooperation among interest groups of different countries in the trade bloc. Their general conclusion therefore suggests that regional integration entails a preference-dilution effect for protectionist interests. On the one hand, 
integration increases both the size and the number of interest groups at the regional level, which in turn become impaired by the free riding problem. Consequently, the political clout of each pressure group diminishes, while trade authorities at the regional level become less responsive to specific interests.

The purpose of this paper has been to contribute to this debate by offering a different perspective on the analysis of the pressures for protection in the context of regional integration. Two principal factors have been identified: the free riding problem and anti-protectionist forces. The main conclusions of this study are the following.

(1) Contrary to the OIson logic of collective action, pressure groups may seek protection more actively in a regional integration area with their size increased (even though the free riding problem increased) than prior to the trade bloc formation.

(2) To the extent that geographical dispersion broadens the political support of protection-seeking groups (as argued in the adding-machine model), regional integration may enhance the political clout of an industry scattered over the union.

(3) Pressure groups may take advantage of the opportunities for economies of scale in protection-seeking activities generated by regional integration.

(4) Demand for (external) protection on the part of industries (allegedly) negatively affected by internal trade liberalization may increase as a "compensation" for regional integration.

(5) There is no systematic empirical support for:

(a) the free riding hypothesis (at least in its strong version),

(b) the significance of industrial concentration to influence political out- 
reduce, or even negate, the free rider problem and the dilution of preference of protectionist interests in an RTA.

(7) Since the benefits from protection are concentrated whereas the costs are diffused, it is likely that protectionist interests will experience a rela tive reinforcement of their preferences compared to anti-protection forces.

Conclusions (1) to (6) suggest that protection-seeking groups may not experience an absolute dilution of their preferences; while conclusion (7) indicates that even if this were not the case (i.e., the former conclusions did not hold), protectionist interests are most likely to experience a relative reinforcement of their preferences (over anti-protectionist forces). Overall, the analysis presented in this paper suggests that, although regionalism does not need to foster the demand for external trade restrictions, it would be misleading to assume that specific interest groups favoring protection will automatically experience a dilution of their preferences in an RTA.

\section{References}

Amelung, Torsten [1989], "The Determinants of Protection in Developing Countries: An Extended Interest-Group Approach," Kyklos 42 (4); pp. 515-532.

Anderson, Kym, and Robert E. Baldwin [1981], "The Political M arket for Protection in Industrial Countries: Empirical Evidence," World Bank Staff Working Paper, N o. 492, October, Washington, D.C.: The World Bank.

Atlas, Cary M ., Robert J. Hendershott, and M ark A. Zupan [1997], "O ptimal E ffort Allocation by U.S. Senators: The Role of Constituency Size," 
Formation in Rent-Seeking Contests," Public Choice 83 (1-2) , April; pp. 113-126.

Baldwin, Robert E. [1985], The Political Economy of U.S. Import Policy, Cambridge, M ass.: The MIT Press.

Baldwin, Richard [1993], "Asymmetric Lobbying Effects: Why Governments Pick Losers," mimeo, September.

Becker, Gary S. [1983], "A Theory of Competition Among Pressure Groups for Political Influence," Quarterly J ournal of E conomics 98 (3), August; pp. 371-400.

Bergstrom, Theodore, Lawrence Blume, and Hal Varian [1986], "On the Private Provision of Public Goods," Journal of Public E conomics 29; pp. 2549.

Bhagwati, Jagdish, and Arvind Panagariya [1996], "The Theory of Preferential Trade Agreements: Historical Evolution and Current Trends," American Economic Review 86 (2), M ay; pp. 82-87.

Bilal, Sanoussi [1997], "Institutional Reforms and the Demand for Protection: Administered Versus Political Protection," Working Paper, N 0. 97.02, April, Department of E conomics, University of Geneva.

Bilal, Sanoussi [1998], "Political E conomy Considerations on the Supply of Trade Protection in Regional Integration Agreements," Journal of Common Market Studies 36(1), M arch; pp. 1-31.

B ohara, Alok K., and William H. Kaempfer [1991], "A Test of Tariff Endogeneity in the United States," American Economic Review 81 (4), September; pp. 952-960.

Brubaker, E.R. [1975], “F ree Ride, Free Revelation, or Golden Rule?," Jour nal of Law and E conomics 18; pp. 147-161.

Caves, Richard E. [1976], "Economic M odels of Political Choice: Canada's Tariff Structure," Canadian Journal of Economics 9 (2), M ay; pp. 278- 
Downs, Anthony [1957], An Economic Theory of Democracy, New York: Harper and Bros.

Eichenberg, Jürgen, and David Kelsey [1996], "Free Riders Do Not Like Uncertainty," Discussion Paper, N 0. 96-14, Department of E conomics, University of Birmingham.

Epstein, Edwin S. [1980], "Firm Size and Structure, M arket Power and Business Political Influence: A Review of the Literature," in Siegfried, John J. (eds.), The Economics of Firm Size, Market Structure and Social Per formance, July, Washington, D.C.: U.S. Government Printing Office; pp. 240-281.

Esty, Daniel C., and Richard E. Caves [1983], “M arket Structure and Political Influence: New Data on Political Expenditure, Activity and Success," Economic Inquiry 21, January; pp. 24-38.

Findlay, Ronald [1993], "Discussion," in M elo, Jaime de, and Arvind Panagariya eds., New Dimensions in Regional Integration, Cambridge: Cambridge University Press, (ch.6); pp. 193-199.

Finger, J. M ichael, H. Keith Hall, and Douglas R. N elson [1982], "The Political Economy of Administered Protection," American E conomic Review 72 (3); pp. 452-466.

Fon, Vincy [1988], "F ree-Riding Versus Paying Under Uncertainty," Public Finance Quarterly 16 (4), October; pp. 464-481.

Frankel, J effrey, Ernesto Stein, and Shang-jin Wei [1996], "Regional Trading Arrangements: Natural or Supranatural," American Economic Review 86 (2), M ay; pp. 52-56.

Glazer, Amihai, Henry M cM illan, and M arc Robbins [1985], "Politics and Corporate Profits," Irvine E conomics Paper, No. 85-22, University of California.

Godek, Paul E. [1985], “Industry Structure and Redistribution Through 
Economic Journal 57 (3), J anuary; pp. 727-738.

Grier, Kevin B., M ichael C. M unger, and Brian E. Roberts [1994], "The Determinants of Industry Political Activity, 1978-1986," American Polit ical Science Review 88 (4), December; pp. 911-926.

Grossman, Gene M., and Elhanan Helpman [1995], "The Politics of Free Trade Agreements," American Economic Review 85 (4), September; pp. 667-690.

Guttman, Joel M . [1991], "Voluntary Collective Action," in Hillman, Arye L. ed., M arket and Politicians: Politicized Economic Choice, B oston: Kluwer, ch. 2; pp. 27-41.

Hallett, Andrew Hughes, and C.A. Primo Braga [1994], "The New Regionalism and the Threat of Protectionism," Journal of the Japanese and International E conomies 8 (4), December; pp. 388-421.

Hansen, Stephen, Thomas R. Palfrey, and Howard Rosenthal [1987], "The Downsian M odel of Participation: Formal Theory and Empirical Analysis of the Constituency Size Effect," Public Choice 52; pp. 15-33.

Hansen, Wendy L., and Thomas J. Prusa [1995], "The Road M ost Taken: The Rise of Title VII Protection," World Economy 18 (2), M arch; pp. 295-313.

Helleineir, G.K. [ 1977], “The Political Economy of Canada's Tariff Structure: An Alternative Model," Canadian Journal of Economics 10 (2), May; pp. 318-329.

Henriques, Irene, and Perry Sadorsky [1994], "The Determinants and Persistance of Canadian Tariff Rates," Canadian Journal of E conomics 27 (1), February; pp. 112-128.

Hirshleifer, Jack [1983], "From Weakest-Link to Best-Shot: The Voluntary Provision of Public Goods," Public Choice 41; pp. 371-386.

Isaac, R. M ark, J ames W. Walker, and Susan H. Thomas [1984], "Divergent 
Regionalism in Agricultural Trade," American Journal of Agricultural Economics 75 (3), August; pp. 803-809.

Kahane, Leo H. [1992], "The Political Economy of Israeli Protectionism: An Empirical Analysis," Public Choice 74 (3), October; pp. 339-353.

Kim, Olive, and M ark Walker [1984], "The Free Rider Problem: Experimental Evidence," Public Choice 43; pp. 2-24.

Krishna, Kala, and Anne Krueger [1995], "Implementing Free Trade Areas: Rules of Origin and Hidden Protectionism," NBER Working Paper, No. 4983, January, Cambridge, Mass.: National Bureau of Economic Research.

Krueger, Anne O. [1993], "Free Trade Agreements as Protectionist Devices: Rules of Origin," NBER Working Paper, No. 4352, April, Cambridge, $M$ ass.: $N$ ational Bureau of Economic Research.

Krueger, Anne O. [1995], "F ree Trade Agreements Versus Customs Unions," NBER Working Paper, No. 5084, April, Cambridge, Mass.: National Bureau of Economic Research.

Krugman, Paul [1993], "Regionalism versus M ultilateralism: Analytical Notes," in M elo, Jaime de, and Arvind Panagariya (eds.), New Dimen sions in Regional Integration, Cambridge: Cambridge U niversity Press, ch. 3; pp. 58-79.

Lavergne, Real P. [1983], The Political E conomy of U.S. Tariffs: An Empirical Analysis, Toronto: Academic Press Canada.

Lee, Jong-Wha, and Phillip Swagel [1994], "Trade Barriers and Trade Flows Across Countries and Industries," NBER Working Paper, N 0. 4799, July, Cambridge, $M$ ass.: National Bureau of Economic Research.

Leidy, M ichael P. [1997], "M acroeconomic Conditions and Pressures for Protection under Antidumping and Countervailing Duty Laws: Empirical Evidence from the United States," I M F Staff Papers 44 (1), M arch; 
M cGuire, M artin [1974], "Group Size, Group Homogeneity, and the Aggregate Provision of a Pure Public Good Under Cournot Behavior," Public Choice 18, Summer; pp. 107-126.

M achlup, Fritz [1977], A History of Thought on E conomic Integration, N ew York: Columbia University Press.

Magee, Stephen P., William A. Brock, and Leslie Young [1989], Black H ole Tariffs and Endogenous Policy Theory: Political Economy in General Equilibrium, Cambridge: Cambridge U niversity Press.

M ansfield, Edward.D., and M arc L. Busch [1995], "The Political E conomy of N on-Tariff Barriers: A Cross-N ational Analysis," International Orga nization 49 (4), Autumn; pp. 723-749.

Marks, Stephen V., and John M cArthur [1990], "E mpirical Analyses of the Determinants of Protection: A Survey and Some New Results," in Odell, J ohn S., and Thomas D. Willett (eds.), International Trade Poli cies: Gains from Exchange between Economics and Political Science, Studies in International Trade Policy, Ann Arbor: The University of M ichigan Press, ch. 5; pp. 105-139.

M arvel, Howard P., and Edward J. Ray [1983], "The Kennedy Round: Evidence on the Regulation of International Trade in the United States," American Economic Review 73 (1); pp. 190-197.

M arwell, Gerald, and Ruth E. Ames [1979], "Experiments on the Provision of Public Goods. I. Resources, Interest, Group Size, and the Free-Rider Problem," American Journal of Sociology 84 (6), M ay; pp. 1335-1360.

Melo, Jaime de, Arvind Panagariya, and Dani Rodrik [1993], "The New Regionalism: A Country Perspective," in M elo, J aime de, and Arvind Panagariya (eds.), New Dimensions in Regional Integration, Cambridge: Cambridge University Press, ch. 6; pp. 159-193.

M esserlin, Patrick [1982], “Les Déterminants de la Demande de Protection: 
M unger, M ichael C. [1988], "On the Political Participation of the Firm in the Electoral Process: An U pdate," Public Choice 56 (3); pp. 295-298.

M urphy, Kevin M., Andrei Schleifer, and Robert W. Vishny [1991], "The Allocation of Talent: Implication for Growth," Quarterly Journal of Eco nomics 106, M ay; pp. 503-530.

M urphy, Kevin M., Andrei Shleifer, and Robert W. Vishny [1993], "Why Is Rent-Seeking So Costly to Growth?," American E conomic Review 83 (2), M ay; pp. 409-414.

Olson, M ancur [1965], The Logic of Collective Action: Public Goods and the Theory of Groups, Cambridge, M ass.: H arvard University Press.

Panagariya, Arvind, and Ronald Findlay [1996], "A Political Economy Analysis of Free Trade Areas and Customs Unions," in Feenstra, Robert, Douglas Irwin, and Gene Grossman (eds.), The Political Economy of Trade Reform, Cambridge, M ass.: The M IT Press.

Peltzman, Sam [1976], "Toward a M ore General Theory of Regulation," Journal of Law and E conomics 19 (2), August; pp. 211-240.

Pecorino, Paul [1996], "Is There a Free-Rider Problem in Lobbying? Endogenous Tariffs, Trigger Strategies, and the Number of Firms," mimeo, Department of Economics, Finance and Legal Studies, University of Alabama.

Pincus, J. J . [1975], "Pressure Groups and the Pattern of Tariffs," Journal of Political Economy 83 (4), August; pp. 757-778.

Pittman, Russell [1976], "The Effects of Industry Concentration and Regulation on Contributions in Three 1972 U.S. Senate Campaigns," Public Choice 27; pp. 71-80.

Pittman, Russell [1977], "M arket Structure and Campaign Contributions," Public Choice 31; pp. 37-52.

Pittman, Russell [1988], "Rent-Seeking and M arket Structure: Comment," 
Economics and Politics 6 (3), November; pp. 215-232.

Ray, Edward J ohn [1981a], "The Determinants of Tariff and N ontariff Trade Restrictions in the United States," Journal of Political E conomy 89 (1), February; pp. 105-121.

Ray, Edward John [1981b], "Tariff and Nontariff Barriers to Trade in the United States and Abroad," Revi ew of Economics and Statistics 63 (2), May; pp. 161-168.

Ray, Edward J ohn [1990], "E mpirical Research on the Political E conomy of Trade," in Carter, Colin A., Alex F. M cCalla, and J effrey A. Sharples (eds.), Imperfect Competition and Political Economy: The New Trade Theory in Agriculture Trade Research, B oulder: Westview Press, ch.7; pp. 175-214.

Riaz, Khalid, Jason F. Shogren, and Stanley R. J ohnson [1995], "A General M odel of Rent Seeking for Public Goods," Public Choice 82 (3-4), $M$ arch; pp. 243-259.

Richardson, M artin [1994], "Why a Free Trade Area? The Tariff Also Rises," Economics and Politics 6 (1), M arch; pp. 79-96.

Rogowski, Ronald [1987], "Trade and the Variety of Democratic Institutions," International Organization 41 (2), Spring; pp. 203-223.

Sager, M ichelle A. [1997], "Regional Trade Agreements: Their Role and the Economic Impact on Trade Flows," World Economy 20 (2), M arch; pp. 239-252.

Salamon, Lester M., and J ohn J. Siegfried [1977], "Economic Power and Political Influence: The Impact of Industry Structure on Public Policy," American Political Science Review 71 (3), September; pp. 1026-1043.

Sandler, Todd [1992], Collective Action: Theory and A pplications, New York: Harvester Wheatsheaf.

Saunders, Ronald S. [1980], "The Political Economy of E ffective Tariff Pro- 
nal of E conomics and M anagement Science 2; pp. 3-21.

Stigler, George J. [1974], "Free Riders and Collective Action: An Appendix to Theories of Economic Regulation," Bell Journal of Economics and M anagement Science 5 (2); pp. 359-365.

Tharakan, P.K.M . [1980], "The Political Economy of Protection in Belgium," World Bank Staff Working Paper, N o. 431, October, Washington, D.C.: The World Bank.

Trefler, Daniel [1993], "Trade Liberalization and the Theory of Endogenous Protection: An E conometric Study of the U.S. Import Policy," Journal of Political E conomy 101 (1), February; pp. 138-160.

Winters, L. Alan [1996], "Regionalism versus M ultilateralism," CEPR Discus sion Paper, N 0.1525, London: Centre for E conomic Policy Research.

WTO [1995], Regionalism and the World Trading System, April, Geneva: World Trade Organization.

Zardkoohi, Asghar [1985], "On the Political Participation of the Firm in the Electoral Process," Southern Economic J ournal 51, January; pp. 804-817.

Zardkoohi, Asghar [1988], "M arket Structure and Campaign Contributions: Does Concentration Matter? A Reply," Public Choice 58 (2), August; pp. 187-191. 